\title{
Antiviral Activity of Synthetic Peptides Derived from Physiological Proteins
}

\author{
Arianna Sala ${ }^{a}$ Andrea Ardizzoni ${ }^{a}$ Tecla Ciociola ${ }^{b}$ Walter Magliani ${ }^{b}$ \\ Stefania Conti ${ }^{b}$ Elisabetta Blasi ${ }^{a} \quad$ Claudio Cermelli ${ }^{a}$ \\ aDepartment of Diagnostic, Clinic and Public Health Medicine, University of Modena and Reggio Emilia,

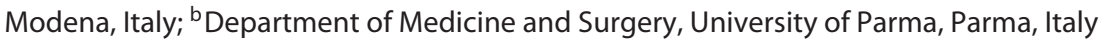

\section{Keywords}

Antiviral activity Peptides . Antimicrobial peptides .

Herpes simplex virus 1 - Adenovirus - Vesicular stomatitis virus · Coxsackievirus B5

\section{Abstract}

Background/Aims: New antivirals are needed to supplement or replace currently used drugs. The aim of this study was to evaluate the antiviral activity of synthetic peptides derived from physiological proteins. Methods: Vero cell monolayers were infected with herpes simplex virus 1, vesicular stomatitis virus, adenovirus, and coxsackievirus B5 strains in the presence of different concentrations of the selected peptides and viral yield was determined by plaque reduction assays to evaluate the antiviral activity of the peptides. Virucidal activity was evaluated by determining the residual infectivity of viral suspensions treated for $1 \mathrm{~h}$ with the peptides at the same concentrations as in the viral yield assays. Results: Among the investigated peptides, the killer peptide proved to exert a considerable antiviral activity against herpes simplex virus, attributable to a direct effect on virus particles, while its derivative K10S showed to be effective against the four investigated virus strains only at the highest concentration tested, yet, the inhibitory effects were only partial. Conclusion: Overall, initial evidence is provided on the antiviral activity of several peptides, as well as of their derivatives. Further investigation is warranted to ascertain the mechanism of action in order to develop new potential antiviral drugs.

(c) 2019 S. Karger AG, Basel

\section{Introduction}

Drug-resistant infectious agents are emerging and spreading globally, threatening our ability to treat the relative diseases and resulting in prolonged illness, disability, and even fatal outcome. This ever-growing problem also results in enhancement of health care costs due to prolonged hospitalization, need for additional laboratory tests, and use of more expensive drugs [1,2].

Viruses represent a major cause of disease and mortality worldwide and the emergence of viral drug resistance is of particular concern for public health because of the limited number of antiviral molecules available to date. It is well known that drug misuse produces a selective pressure on viruses during replication, allowing adaptation to

\section{KARGER}

() 2019 S. Karger AG, Basel

E-Mail karger@karger.com

www.karger.com/int
Claudio Cermelli

Department of Diagnostic, Clinic and Public Health Medicine

University of Modena and Reggio Emilia, Via Campi 287

IT-41125 Modena (Italy)

E-Mail claudio.cermelli@unimore.it 
antiviral treatment and emergence of resistant strains [3]. The consequences of newly acquired resistance are particularly serious in chronic infections, as those caused by $\mathrm{HIV}, \mathrm{HBV}$ and HCV, likely resulting in therapeutic failure. Moreover, the costs of new drugs are extremely high, rendering these therapies unaffordable in developing countries. Therefore, new antivirals are urgently needed to supplement or replace existing drugs [1,2]. In this context, particular attention has recently been focused on naturally occurring or synthetic peptides endowed with antiviral activity, as potential alternatives to current therapeutic agents [4-7].

Antimicrobial peptides (AMPs) or, more generally, host defense peptides, are commonly considered as immunity primitive mechanisms and have been extensively studied in a wide variety of organisms, from microbes to plants, insects and vertebrates, including humans [8-13]. AMPs share common features regardless of their different origins: they are relatively short (10-50 amino acids), mostly positively charged, and amphipathic; interestingly, they exhibit different properties, based on their structural characteristics. Their range of activity usually includes bacteria, fungi, and protozoa, but also antiviral activity has been shown for several AMPs [14-17].

Biologically active peptides, defined as cryptides or crypteins, may also derive from proteolytic cleavage of physiological proteins, including, among others, hemoglobin, components of the complement cascade, and milk proteins $[18,19]$. Cryptides may exhibit a broad spectrum of biological activities, different from those of the precursor proteins.

A peculiar group of cryptides are those derived from either the variable or the constant regions of antibodies (Abs) [20-22]. In particular, the killer peptide (KP), the leading compound of a group of Ab-derived fragments endowed with various biological activities, has been widely investigated. It is a decapeptide, derived from the variable region of an anti-idiotypic Ab representing the functional internal image of a yeast killer toxin, endowed with a wide spectrum of antimicrobial activity [23, 24]. To date, KP has shown an outstanding activity against many different infectious agents, including HIV and influenza A viruses, through different mechanisms of action [25, 26]. Here, we expanded this issue, investigating the activity of KP against viruses with different morphology (enveloped vs. nonenveloped) and genome type (DNA vs. RNA). In addition, we studied other peptides, derived from human serum proteins, including Abs, albumin, fibrinogen, $\mathrm{C} 3 \mathrm{c}$ and $\mathrm{C} 4$ complement fragments, and peptides encoded by immunoglobulin genes.

Antiviral Peptides from Physiological

Proteins

\section{Materials and Methods}

\section{Cell Line}

The Vero cell line was used for all the experiments. Cells were cultured at $37^{\circ} \mathrm{C}$ in $5 \% \mathrm{CO}_{2}$ atmosphere in Dulbecco's minimum essential medium containing 10\% (growth medium) or 5\% (maintenance medium) fetal bovine serum, penicillin $(100 \mathrm{U} / \mathrm{mL})$, streptomycin $(100 \mu \mathrm{g} / \mathrm{mL})$, ciprofloxacin $(100 \mu \mathrm{g} / \mathrm{mL})$, and L-glutamine ( $2 \mathrm{mM})$. Cells were maintained by biweekly passages in fresh medium.

\section{Viruses}

Herpes simplex virus 1 (HSV-1), coxsackievirus B5 (CoxV B5), adenovirus (AdV), and vesicular stomatitis virus (VSV) strains used in this study were clinical isolates, identified by monoclonal antibodies and laboratory adapted through serial passages $(>50)$ on Vero cells [27]. Viral suspensions used as inocula were obtained from centrifuged lysates of virus-infected Vero cells, cultured in serum-free medium. All the experiments were carried out in medium without fetal bovine serum in order to avoid interactions between serum components and peptides. Virus batches were titrated on Vero cells, aliquoted and kept frozen at $-80^{\circ} \mathrm{C}$.

Peptides

The investigated peptides were synthesized by solid-phase peptide synthesis using a multiple peptide synthesizer (SyroII, MultiSynTech GmbH), at the CRIBI Biotechnology Center (University of Padua, Italy). Peptide purity was $>90 \%$ as evaluated by analytical reverse-phase HPLC. The peptides were solubilized in dimethylsulfoxide at a concentration of $20 \mathrm{mg} / \mathrm{mL}$ and subsequently diluted in phosphate-buffered saline for experimental use. The origin and the amino acid sequence of the peptides used in the study are reported in Table 1.

\section{Evaluation of Peptide Cytotoxicity by MTT Assay}

The colorimetric 3-(4,5-dimethylthiazol-2-yl)-2,5-diphenyltetrazolium bromide (MTT) assay was used to evaluate the effects of different concentrations of peptides on Vero cell viability. Briefly, cell cultures grown in monolayer in 96-well plates were treated with the peptides, starting from 10,50 , and $100 \mu \mathrm{g} / \mathrm{mL}$, and, only for $\mathrm{KP}$, up to $800 \mu \mathrm{g} / \mathrm{mL}$ in order to obtain the $90 \%$ cytotoxicity concentration $\left(\mathrm{CC}_{90}\right)$, and incubated for $24 \mathrm{~h}$ at $37^{\circ} \mathrm{C}$. Then, the MTT assay was carried out as previously described [28]. Cell viability was expressed as optical density percentage of the treated cultures compared to that of the untreated controls (100\% viability). $\mathrm{CC}_{90}$ was calculated by regression analysis, as the peptide concentration capable of reducing the optical density in the MTT assay by $90 \%$ in comparison to control.

\section{Evaluation of Peptide Antiviral Activity}

In order to preliminarily select peptides endowed with a potential antiviral activity, a plaque reduction assay (PRA) was initially performed [29]. Briefly, Vero cells grown in 96-well culture plates $\left(2 \times 10^{4}\right.$ cells/well $)$ for $24 \mathrm{~h}$ at $37^{\circ} \mathrm{C}$ were infected with $25 \mu \mathrm{L}$ of serum-free medium containing the different viruses under study diluted to $10^{4}$ plaque-forming units (PFUs) $/ \mathrm{mL}$ with or without (as negative control) each peptide at a concentration of $10 \mu \mathrm{g} / \mathrm{mL}$. After $1 \mathrm{~h}$ of incubation to allow viral adsorption, the inoculum was removed and serum-free medium $(200 \mu \mathrm{L} /$ well $)$ containing $0.6 \%$ $\mathrm{v} / \mathrm{v}$ human Ig (Ig VENA, Kedrion, Lucca, Italy) with or without 
Table 1. Amino acid sequence and origin of the investigated peptides

\begin{tabular}{|c|c|c|}
\hline Peptide & Amino acid sequence & Origin \\
\hline KP & AKVTMTCSAS & $\begin{array}{l}\text { peptide derived from the variable region of an anti-idiotypic Ab } \\
\text { representing the functional internal image of a yeast killer toxin [24] }\end{array}$ \\
\hline K10S & KKVTMTCSAS & $\mathrm{KP}$ derivative \\
\hline $\mathrm{N} 10 \mathrm{~K}$ & NQVSLTCLVK & fragment of the constant region of human IgG1 [21] \\
\hline N1A & AQVSLTCLVK & N10K alanine-substituted derivative \\
\hline L5A & NQVSATCSVK & N10K alanine-substituted derivative \\
\hline L8S & NQVSLTCSVK & N10K alanine-substituted derivative \\
\hline K13L & KKLVAASQAALGL & fragment of human albumin [43] \\
\hline $\mathrm{D} 15 \mathrm{R}$ & DSGEGDFLAEGGGVR & fragment of fibrinogen $\alpha$-chain [43] \\
\hline D15T & DEAGSEADHEGTHST & fragment of fibrinogen $\alpha$-chain [43] \\
\hline G17K & GLEEELQFSLGSKINVK & fragment of $\alpha$-chain of complement C4 [43] \\
\hline S17K & SEETKENEGFTVTAEGK & fragment of $\alpha$-chain of complement C3c $[20,43]$ \\
\hline G10S & GYCSGGSCYS & peptide encoded by immunoglobulin genes [32] \\
\hline $\mathrm{L} 12 \mathrm{P}$ & LCLRNWDQGHRP & peptide encoded by immunoglobulin genes [32] \\
\hline
\end{tabular}

(negative control) each peptide $(10 \mu \mathrm{g} / \mathrm{mL})$ was added to each well. After $24 \mathrm{~h}$ of incubation, the cells were fixed with methanol and stained with crystal violet. Plaques were scored visually and PFUs were enumerated. Each assay was performed in triplicate.

The antiviral activity of the selected peptides against the different viral strains was then evaluated by the viral yield reduction assay. Vero cells monolayers were infected for $1 \mathrm{~h}$ at $37^{\circ} \mathrm{C}$ with virus inocula in the presence of peptides (final concentrations 10,50 , and $100 \mu \mathrm{g} / \mathrm{mL}$ ) or without peptides (control). After $1 \mathrm{~h}$ of adsorption at $37^{\circ} \mathrm{C}$, viral inocula were removed and serum-free medium containing peptides at the same concentration used for the inocula, or medium alone (control), was added. Each assay was performed in triplicate. After $24 \mathrm{~h}$ of incubation at $37^{\circ} \mathrm{C}$, the supernatants were harvested, and virus yields were titrated by PRA on Vero cell monolayers [29]. Briefly, Vero cells were seeded in 24well plates $\left(1.5 \times 10^{5}\right.$ cells/well $)$ and infected with $200 \mu \mathrm{L}$ of 10 -fold serial dilutions of the samples to be titrated. After $1 \mathrm{~h}$ of incubation, the inoculum was removed and $200 \mu \mathrm{L}$ of maintenance medium containing $0.6 \% \mathrm{v} / \mathrm{v}$ human Ig was added to each well. After $48-$ $72 \mathrm{~h}$ of incubation, the cells were fixed and stained, then plaques were scored visually, and virus titers were expressed as PFU/mL. Results were expressed as percent viral yield in comparison to control (100\%).

\section{Evaluation of Inhibitory Concentration 90 and Selectivity} Index

The $90 \%$ inhibitory concentration $\left(\mathrm{IC}_{90}\right)$ was established for the most active peptide by PRA. Vero cell monolayers were infected with virus inocula containing 2 -fold peptide dilutions. After incubation, the inocula were removed and serum-free medium, containing $0.6 \% \mathrm{v} / \mathrm{v}$ human Ig and peptide at the same concentrations used for the inocula, was added to each well. After $24 \mathrm{~h}$ of incubation, the cells were fixed, stained and PFUs enumerated. $\mathrm{IC}_{90}$ was calculated by regression analysis as the peptide concentration capable of reducing the number of PFU by $90 \%$ in comparison to control (infected cells in the absence of peptide). The selectivity index (SI) was calculated as the ratio between the $\mathrm{CC}_{90}$ and the $\mathrm{IC}_{90}$ values.

\section{Evaluation of Peptide Virucidal Activity}

To evaluate whether the antiviral activity of the investigated peptides could be due to a direct viral inactivation by interaction with virus particles before adsorption, viral suspensions $\left(10^{4}\right.$ PFUs $/ \mathrm{mL}$ ) were treated with peptides at concentrations of 10,50 , and $100 \mu \mathrm{g} / \mathrm{mL}$ and incubated for $1 \mathrm{~h}$ at $37^{\circ} \mathrm{C}$. The residual infectivity of the samples was then titrated by PRA as described above.

\section{Statistical Analysis}

The data reported in figures are the mean values $( \pm$ standard errors) from at least 3 independent experiments. Data were analyzed by one-way ANOVA with the Bonferroni post hoc test. A $p$ value $<0.05$ was considered as statistically significant.

\section{Results}

\section{Peptide Cytotoxicity on Vero Cells}

By MTT assay, we preliminarily evaluated the cytotoxic effects (if any) of the peptides on Vero cells. At the lowest concentration(s) tested, a negligible toxicity $(<10 \%)$ was observed (data not shown), irrespective of the peptide tested, and also at the highest concentration (100 $\mu \mathrm{g} / \mathrm{mL}$ ), 7 peptides (KP, D15R, D15T, G17K, S17K, G10S, L12P) caused only a small reduction of Vero cells viability $(2-10 \%)$ in comparison with the untreated control. Differently, at the same concentration $(100 \mu \mathrm{g} / \mathrm{mL}), 4$ peptides (N10K, L8S, L5A, K10S) reduced cell viability of approximately $20 \%$, while N1A and K13L showed the highest effects (40 and 30\% reduction of viability, respectively). On the basis of these data, further experiments were performed at 3 peptide concentrations, namely 10 , 50 , and $100 \mu \mathrm{g} / \mathrm{mL}$. 


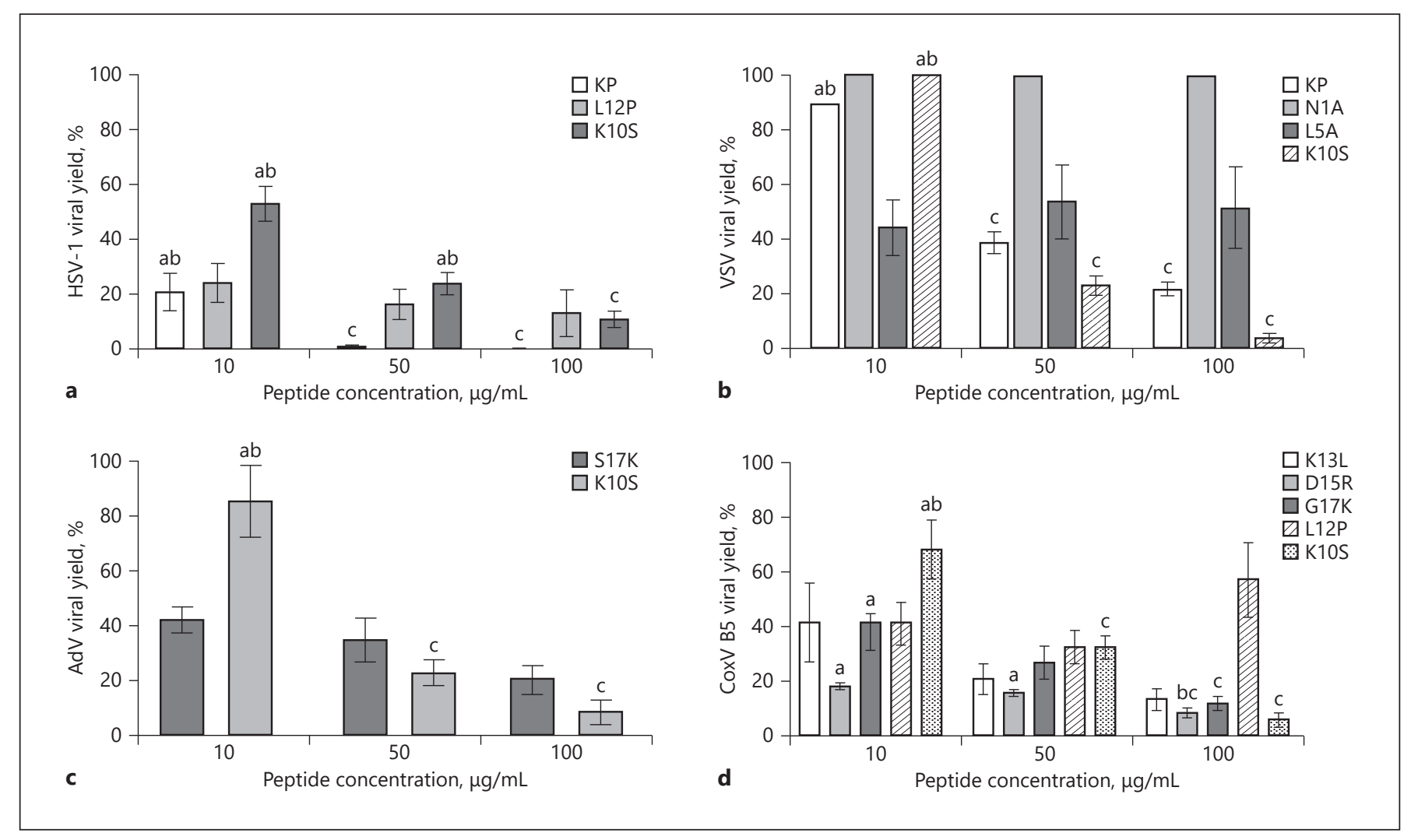

Fig. 1. Antiviral activity of the peptides, as evaluated by the viral yield reduction assay. Vero cells were infected with HSV-1 (a), VSV (b), AdV (c), and CoxV B5 (d) and treated with the selected peptides at 3 concentrations $(10,50$, and $100 \mu \mathrm{g} / \mathrm{mL})$. Twenty-four hours following infection, virus yield was determined by PRA. Vi-

\section{Peptide Antiviral Activity}

On the basis of preliminary data obtained by PRA, where the 4 viruses were challenged with each peptide at a concentration of $10 \mu \mathrm{g} / \mathrm{mL}$ (data not shown), we selected a limited number of peptides for further analysis against the different viruses by viral yield reduction assays. In particular, KP, L12P, and K10S were tested against HSV-1; KP, N1A, L5A, and K10S against VSV; S17K and K10S against AdV; K13L, D15R, G17K, L12P, and K10S against CoxV B5. Each peptide was tested at three different concentrations. The results, expressed as a percentage of viral yield compared to the controls (medium without peptide), are shown in Figure 1. With respect to HSV-1 (Fig. 1a), none of the selected peptides (KP, L12P, and K10S) showed an appreciable antiviral activity, i.e., a viral yield $<10 \%$ in comparison to controls (100\% infectivity), when used at the lowest concentration $(10 \mu \mathrm{g} / \mathrm{mL})$. However, $\mathrm{KP}$ caused a high inhibition at 50 and $100 \mu \mathrm{g} / \mathrm{mL}$, with a viral yield of 0.4 and $0.03 \%$, respectively. L12P and K10S caused a

ral yield percentages of peptide-treated cells in comparison with mock-treated cells (100\% yield) are reported as mean \pm standard errors of 3 independent experiments. $p<0.05$ for 10 and/or $50 \mu \mathrm{g} /$ $\mathrm{mL}$ vs. $100 \mu \mathrm{g} / \mathrm{mL}$ (a); $p<0.05$ for 10 and/or $100 \mathrm{vs.} 50 \mu \mathrm{g} / \mathrm{mL}$ (b); $p<0.05$ for 50 and/or 100 vs. $10 \mu \mathrm{g} / \mathrm{mL}$ (c).

weaker inhibition, with a viral yield of 16 and $24 \%$, at 50 $\mu \mathrm{g} / \mathrm{mL}$, and 13 and $11 \%$ at $100 \mu \mathrm{g} / \mathrm{mL}$, respectively.

K10S was also tested against VSV, giving an approximately $4 \%$ virus yield at $100 \mu \mathrm{g} / \mathrm{mL}$ (Fig. $1 \mathrm{~b}$ ). The other peptides assessed against VSV, namely KP, N1A, and L5A, did not show remarkable antiviral effects, at any concentration.

When the peptides S17K and K10S were tested against AdV (Fig. 1c), K10S gave an appreciable inhibition, with a viral yield of $9 \%$ in comparison with the control, at the highest concentration, while no significant antiviral activity was obtained with S17K.

The peptides K13L, D15R, G17K, L12P, and K10S were tested against CoxV B5 (Fig. 1d). None of them exhibited a significant activity at 10 and $50 \mu \mathrm{g} / \mathrm{ml}$. With the exception of L12P, when used at $100 \mu \mathrm{g} / \mathrm{ml}$, the other peptides showed a modest inhibiting activity, with a mean viral yield of approximately 13\% (K13L), 8\% (D15R), 12\% (G17K), and 6\% (K10S). 


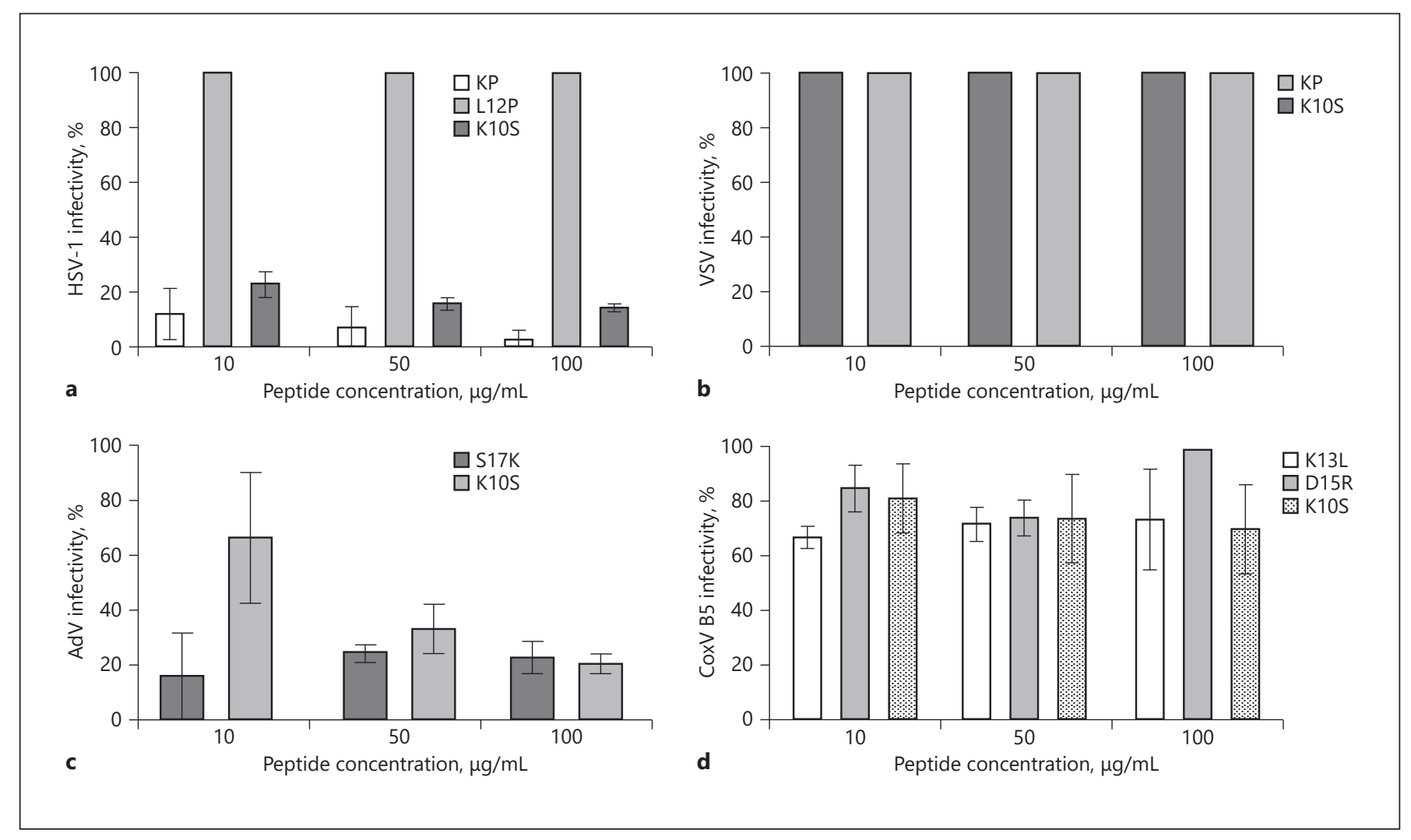

Fig. 2. Virucidal activity of the peptides. Viral suspensions of HSV-1 (a), VSV (b), AdV (c), and CoxV B5 (d) were treated with the selected peptides at 3 concentrations $(10,50$, and $100 \mu \mathrm{g} / \mathrm{mL})$ for $1 \mathrm{~h}$ at $37^{\circ} \mathrm{C}$ in serum-free medium, then the residual infectivity was determined by PRA. Infectivity percentages of peptide-

Considering the remarkable antiviral activity displayed by KP against $\mathrm{HSV}-1$, the $\mathrm{CC}_{90}, \mathrm{IC}_{90}$, and SI were determined. The $\mathrm{CC}_{90}$ of $\mathrm{KP}$, evaluated by the MTT assay, was $2,943 \mu \mathrm{g} / \mathrm{mL}$, while the $\mathrm{IC}_{90}$ was $58 \mu \mathrm{g} / \mathrm{mL}$; consequently, the SI value was 50.74 .

\section{Peptide Virucidal Activity}

In order to evaluate whether the antiviral activity observed for some peptides was related to a direct interaction with the viral particles, each virus was pretreated with any selected peptide at 3 different concentrations for $1 \mathrm{~h}$; then, the residual infectivity was titrated by PRA. The results, expressed as percent infectivity in comparison to controls (virus without peptide), are shown in Figure 2. Only KP showed a direct activity against HSV-1 (Fig. 2a), since the percent infectivity dropped to $13 \%$ (at $10 \mu \mathrm{g} /$ $\mathrm{mL}$ ) and $3.3 \%$ (at $100 \mu \mathrm{g} / \mathrm{mL}$ ) compared to the $100 \%$ infectivity of the control. No other peptide, even if displaying a considerable antiviral activity as assessed by viral treated viral suspensions in comparison with mock-treated control (100\% infectivity) are reported as mean \pm standard errors of 3 independent experiments. No significant difference was observed between the different concentrations of the peptides.

yield assay (Fig. 1), showed a direct virucidal activity against the other viruses tested (Fig. 2b-d).

\section{Discussion}

The lack of therapeutic agents against many important viral infections and the ever-growing problem of drug resistance pose the urgent need for molecules endowed with antiviral activity, possibly also exhibiting a minimal toxicity profile and having limited costs; this would give rise to the development of novel antiviral drugs. In this scenario, increasing interest has arisen for AMPs, a large group of natural molecules present in all micro- and macro-organisms, as an essential part of their own defenses, and for cryptides, known to derive from physiological proteins $[4,5,9,10,30]$. The most intriguing peculiarity of these molecules is the wide-spectrum antimicrobial activity, achieved by a direct action against microbial targets 
or indirectly, via activation of host immune responses [31].

In the present study, we evaluated the antiviral activity of 13 synthetic peptides against 4 viruses, namely HSV-1, CoxV B5, AdV, and VSV, exhibiting different structural features. As described elsewhere, the amino acidic sequences of the selected peptides are comprised in proteins of various origin, including immunoglobulins, human albumin, fibrinogen $\alpha$-chain, and complement fragments. Several studies have already demonstrated a wide-spectrum antimicrobial activity by KP and some of the other peptides [21, 23, 32]. Yet, the antiviral activity of such peptides has not been investigated yet, with the exception of KP, which has been shown to inhibit HIV as well as human and avian influenza viruses $[25,26]$. The results of the present work expand our knowledge on KP, showing that it drastically reduces HSV-1 viral yield, at both $50 \mu \mathrm{g} / \mathrm{mL}$ (99\%) and $100 \mu \mathrm{g} / \mathrm{mL}$ (99.99\%) (Fig. 1a); also, the corresponding $\mathrm{IC}_{90}$ and SI values are $58 \mu \mathrm{g} / \mathrm{mL}$ and 50.74 , respectively.

According to the literature, many different AMPs are able to neutralize enveloped viruses by directly interacting with their lipid membrane, regardless of the nucleic acid nature of the viral genome $[14,33]$. On this basis, we investigated the potential virucidal activity of KP against $\mathrm{HSV}-1$ by preincubating a cell-free viral suspension with this peptide before cell infection: the results show a massive virus inactivation (99\%) (Fig. 2a), thus strongly suggesting that the antiviral activity of KP is mainly mediated by its direct interaction with the virus.

The neutralization of virus infectivity may be ascribed to the presence of hydrophobic amino acids, allowing KP to interact with the envelope lipid bilayer, thus inducing its destabilization. Alternatively, thanks to its positive charge, KP may interact with envelope lipids and/or glycoproteins [34-36]. It is noteworthy that, in our hands, KP fails to have any significant inhibitory activity against the two nonenveloped viruses, AdV and CoxV B5. With regard to the other enveloped virus tested, VSV, KP has shown a scant viral yield inhibition (78\%) (Fig. 1b) and no virucidal activity (Fig. 2b). The different composition and organization of the membranes of HSV-1 and VSV may account for these different results: indeed, while glycoproteins are virus specific, lipids derive from different cell membranes, nuclear or reticular for HSV-1, cytoplasmic for VSV [33, 37, 38].

Previous works have demonstrated an antiviral activity for KP against other enveloped viruses, such as HIV, by internalization of the chemokine receptor type 5 (CCR5) in susceptible cells, and human and avian influ-

Antiviral Peptides from Physiological

Proteins enza viruses, by reduction of viral protein synthesis, in particular M1 and HA $[25,26]$. In both cases, a direct KP interaction with viral envelope has been excluded. Therefore, the HSV -1 inhibition observed in the present study may likely be ascribed to a different mechanism of action.

We show that K10S exhibits a weak antiviral activity against HSV-1 but, differently from KP, a high inhibition of VSV (Fig. 1a, b). This peptide has the same sequence of KP except for a substitution in the first amino acid (Table 1); thus, we suggest that the differences between KP and K10S are due to such a single amino acid substitution. Accordingly, several studies suggest that the interaction between AMPs and viruses depends not only on the overall peptide charge but also on its sequence specificity [33].

Different peptide-virus interactions may allow different mechanisms of action to occur: similarly to KP, K10S is virucidal against HSV-1 but not against VSV, suggesting that viral neutralization is not responsible for VSV yield reduction. Therefore, other mechanisms are likely involved, impacting one or more phases of virus replication. Furthermore, K10S proves to also mildly inhibit AdV (91\% of reduction of viral yield) and CoxV B5 (94\%), both of them being without envelope (Fig. 1c, d). As for $\mathrm{AdV}$, a modest virucidal action has also been observed (80\% reduction of virus infectivity) (Fig. 2c). Different hypotheses can be advanced to explain such results. First, this peptide may interact with capsid proteins, thus reducing virus binding, uncoating or exit from endocytic vesicles $[33,39,40]$. Another mechanism may be suggested, according to the observations of Gounder et al. [41] on the direct interactions between other AMPs and AdV: they demonstrated that the decrease in virion repulsive charge leads to virus particles aggregation and impairment of virus attachment. The same hypothesis can be drawn for S17K, that displays a virucidal activity against AdV similar to that observed for K10S.

Besides K10S, other 3 peptides (K13L, D15R, and G17K) show a reduction of CoxV B5 yield, of about $90 \%$ at $100 \mu \mathrm{g} / \mathrm{mL}$ (Fig. 1d), without any virucidal activity; these findings suggest that, as for K10S against VSV, inhibition of viral replication occurs at stages following virus adsorption.

Overall, our results prove that $\mathrm{KP}$ is the most promising peptide among those tested, with a remarkable inhibition of HSV-1. These findings together with those previously observed against HIV and influenza viruses, candidate $\mathrm{KP}$ as a broad-spectrum antiviral drug, likely correlated with the multiplicity of viral targets. Since a 
single amino acid substitution may change peptide activity, as in K10S, we hypothesize that antiviral properties may be further enhanced by other substitutions in the peptide amino acid sequence. The in vitro data here described on the direct antiviral activity do not supply any information on peptide interactions with host immune system, which are also likely to occur; initial evidence has been provided on such a dual role of some AMPs, including KP $[12,42]$. Finally, since these peptides have peculiar mechanisms of action and, in some cases, they exert their activity directly on viral external structures, the risk of selecting new drug-resistant strains should be minimized [13].

\section{Disclosure Statement}

The authors declare that they have no competing interest.

\section{References}

1 Antonelli G, Turriziani O. Antiviral therapy: old and current issues. Int $J$ Antimicrob Agents. 2012 Aug;40(2):95-102.

2 World Health Organization. Antimicrobial resistance. 2018. Available at: http://www. who.int/mediacentre/factsheets/fs194/en/\# (Accessed: May 11, 2018.)

3 Irwin KK, Renzette N, Kowalik TF, Jensen JD. Antiviral drug resistance as an adaptive process. Virus Evol. 2016 Jun;2(1):vew014.

4 Gwyer Findlay E, Currie SM, Davidson DJ. Cationic host defence peptides: potential as antiviral therapeutics. BioDrugs. 2013 Oct; 27(5):479-93.

5 Lakshmaiah Narayana J, Chen JY. Antimicrobial peptides: possible anti-infective agents. Peptides. 2015 Oct;72:88-94.

6 ElSawy KM, Twarock R, Verma CS, Caves LS. Peptide inhibitors of viral assembly: a novel route to broad-spectrum antivirals. J Chem Inf Model. 2012 Mar;52(3):770-6.

7 Chi XJ, Wang XJ, Wang CY, Cui XJ, Wang XJ. In vitro and in vivo broad antiviral activity of peptides homologous to fusion glycoproteins of Newcastle disease virus and Marek's disease virus. J Virol Methods. 2014 Apr;199: 11-6.

8 Lehrer RI, Ganz T. Antimicrobial peptides in mammalian and insect host defence. Curr Opin Immunol. 1999 Feb;11(1):23-7.

9 Hancock RE. Cationic peptides: effectors in innate immunity and novel antimicrobials. Lancet Infect Dis. 2001 Oct;1(3):156-64.

10 Hancock RE, Sahl HG. Antimicrobial and host-defense peptides as new anti-infective therapeutic strategies. Nat Biotechnol. 2006 Dec;24(12):1551-7.

11 Reddy KV, Yedery RD, Aranha C. Antimicrobial peptides: premises and promises. Int $\mathrm{J}$ Antimicrob Agents. 2004 Dec;24(6):536-47.

12 Steinstraesser L, Kraneburg U, Jacobsen F, AlBenna S. Host defense peptides and their antimicrobial-immunomodulatory duality. Immunobiology. 2011 Mar;216(3):322-33.

13 Zasloff M. Antimicrobial peptides of multicellular organisms. Nature. 2002 Jan; 415(6870):389-95.
14 Daher KA, Selsted ME, Lehrer RI. Direct inactivation of viruses by human granulocyte defensins. J Virol. 1986 Dec;60(3):1068-74.

15 Robinson WE Jr, McDougall B, Tran D, Selsted ME. Anti-HIV-1 activity of indolicidin, an antimicrobial peptide from neutrophils. J Leukoc Biol. 1998 Jan;63(1):94-100.

16 Bastian A, Schäfer H. Human alpha-defensin 1 (HNP-1) inhibits adenoviral infection in vitro. Regul Pept. 2001 Sep;101(1-3):157-61.

17 Barlow PG, Findlay EG, Currie SM, Davidson DJ. Antiviral potential of cathelicidins. Future Microbiol. 2014;9(1):55-73.

18 Autelitano DJ, Rajic A, Smith AI, Berndt MC, Ilag LL, Vadas M. The cryptome: a subset of the proteome, comprising cryptic peptides with distinct bioactivities. Drug Discov Today. 2006 Apr;11(7-8):306-14.

19 Pimenta DC, Lebrun I. Cryptides: buried secrets in proteins. Peptides. 2007 Dec;28(12): 2403-10.

20 Polonelli L, Ciociola T, Elviri L, Zanello PP, Giovati L, Arruda DC, et al. A Naturally Occurring Antibody Fragment Neutralizes Infectivity of Diverse Infectious Agents. Sci Rep. 2016 Oct; 6(1):35018.

21 Polonelli L, Ciociola T, Magliani W, Zanello PP, D'Adda T, Galati S, et al. Peptides of the constant region of antibodies display fungicidal activity. PLoS One. 2012;7(3):e34105.

22 Polonelli L, Pontón J, Elguezabal N, Moragues MD, Casoli C, Pilotti E, et al. Antibody complementarity-determining regions (CDRs) can display differential antimicrobial, antiviral and antitumor activities. PLoS One. 2008 Jun;3(6):e2371.

23 Magliani W, Conti S, Ciociola T, Giovati L, Zanello PP, Pertinhez T, et al. Killer peptide: a novel paradigm of antimicrobial, antiviral and immunomodulatory auto-delivering drugs. Future Med Chem. 2011 Jul;3(9): 1209-31.

24 Polonelli L, Magliani W, Ciociola T, Giovati L, Conti S. From Pichia anomala killer toxin through killer antibodies to killer peptides for a comprehensive anti-infective strategy. Antonie van Leeuwenhoek. 2011 Jan;99(1): $35-41$.
25 Casoli C, Pilotti E, Perno CF, Balestra E, Polverini $\mathrm{E}$, Cassone $\mathrm{A}$, et al. A killer mimotope with therapeutic activity against AIDS-related opportunistic micro-organisms inhibits exvivo HIV-1 replication. AIDS. 2006 Apr; 20(7):975-80.

26 Conti G, Magliani W, Conti S, Nencioni L, Sgarbanti R, Palamara AT, et al. Therapeutic activity of an anti-idiotypic antibody-derived killer peptide against influenza A virus experimental infection. Antimicrob Agents Chemother. 2008 Dec;52(12):4331-7.

27 Mazaheritehrani E, Sala A, Orsi CF, Neglia RG, Morace G, Blasi E, et al. Human pathogenic viruses are retained in and released by Candida albicans biofilm in vitro. Virus Res. 2014 Jan;179:153-60.

28 Cermelli C, Fabio A, Fabio G, Quaglio P. Effect of eucalyptus essential oil on respiratory bacteria and viruses. Curr Microbiol. 2008 Jan;56(1):89-92.

29 Garuti L, Roberti M, Cermelli C. Synthesis and antiviral activity of some N-benzenesulphonylbenzimidazoles. Bioorg Med Chem Lett. 1999 Sep;9(17):2525-30.

30 Iavarone F, Desiderio C, Vitali A, Messana I, Martelli C, Castagnola M, et al. Cryptides: latent peptides everywhere. Crit Rev Biochem Mol Biol. 2018 Jun;53(3):246-63.

31 Jarczak J, Kościuczuk EM, Lisowski P, Strzałkowska N, Jóźwik A, Horbańczuk J, et al. Defensins: natural component of human innate immunity. Hum Immunol. 2013 Sep; 74(9):1069-79.

32 Polonelli L, Ciociola T, Sperindè M, Giovati L, D'Adda T, Galati S, et al. Fungicidal activity of peptides encoded by immunoglobulin genes. Sci Rep. 2017 Sep;7(1):10896.

33 Wilson SS, Wiens ME, Smith JG. Antiviral mechanisms of human defensins. J Mol Biol. 2013 Dec;425(24):4965-80.

34 Mojsoska B, Jenssen H. Peptides and Peptidomimetics for Antimicrobial Drug Design. Pharmaceuticals (Basel). 2015 Jul;8(3):366415

Sala/Ardizzoni/Ciociola/Magliani/Conti/ Blasi/Cermelli 
35 Fujii G, Selsted ME, Eisenberg D. Defensins promote fusion and lysis of negatively charged membranes. Protein Sci. 1993 Aug;2(8): 1301-12.

36 Seidel A, Ye Y, de Armas LR, Soto M, Yarosh W, Marcsisin RA, et al. Cyclic and acyclic defensins inhibit human immunodeficiency virus type-1 replication by different mechanisms. PLoS One. 2010 Mar;5(3):e9737.

37 Mingo RM, Han J, Newcomb WW, Brown JC Replication of herpes simplex virus: egress of progeny virus at specialized cell membrane sites. J Virol. 2012 Jul;86(13):7084-97.
38 Swinteck BD, Lyles DS. Plasma membrane microdomains containing vesicular stomatitis virus $M$ protein are separate from microdomains containing $G$ protein and nucleocapsids. J Virol. 2008 Jun;82(11):5536-47.

39 Nguyen EK, Nemerow GR, Smith JG. Direct evidence from single-cell analysis that human \{alpha\}-defensins block adenovirus uncoating to neutralize infection. J Virol. $2010 \mathrm{Apr}$; 84(8):4041-9.

40 Smith JG, Nemerow GR. Mechanism of adenovirus neutralization by Human alpha-defensins. Cell Host Microbe. 2008 Jan;3(1):11-9.

41 Gounder AP, Wiens ME, Wilson SS, Lu W, Smith JG. Critical determinants of human a-defensin 5 activity against non-enveloped viruses. J Biol Chem. 2012 Jul;287(29):24554-62.
42 Cenci E, Pericolini E, Mencacci A, Conti S, Magliani W, Bistoni F, et al. Modulation of phenotype and function of dendritic cells by a therapeutic synthetic killer peptide. J Leukoc Biol. 2006 Jan;79(1):40-5.

43 Williams D, Ackloo S, Zhu P, Bowden P, Evans KR, Addison CL, et al. Precipitation and selective extraction of human serum endogenous peptides with analysis by quadrupole time-of-flight mass spectrometry reveals posttranslational modifications and lowabundance peptides. Anal Bioanal Chem. 2010 Feb;396(3):1223-47. 